\title{
Reproductive and endocrine effects of active immunization against a testosterone conjugate in the heifer*
}

\author{
C. A. Price†, B. A. Morris $\ddagger$ and R. Webb \\ Department of Reproduction and Growth Physiology, A.F.R.C. Institute of Animal Physiology and \\ Genetics Research, Edinburgh Research Station, Roslin, Midlothian EH25 9PS and $\ddagger$ A.F.R.C., \\ Antibody Development Group, Department of Clinical Biochemistry, University of Guildford, \\ Surrey GU2 $5 X H, U . K$.
}

\begin{abstract}
Summary. Yearling heifers were actively immunized against $8 \mathrm{mg}$ testosterone-3carboxymethyloxime-ovalbumen in Non-Ulcerative Freund's Adjuvant, with or without the addition of Corynebacterium parvum (Groups A and B, respectively; $N=4$ for each group). After the priming injection, Groups A and B were boosted twice at 4-monthly intervals. Control heifers $(N=9)$ were not injected. All treated animals except one gave a measurable antibody response, and all responding animals became anoestrous and displayed ovarian cysts after the first booster injection. There were no apparent differences between treatments, and so results for Groups A and B were pooled.

At 25 weeks after the second booster 3 of the 7 responding, anoestrous heifers resumed cyclicity; one with two consecutive double ovulations, and one with one double ovulation. The 3 rd heifer showed 4 corpora lutea, then became anoestrous again. The 4 remaining acyclic heifers, and the control heifers, were intensively blood sampled; the anoestrous heifers showed significantly higher mean $\mathrm{LH}$ and significantly lower mean FSH concentrations and higher LH pulse frequency than did the control animals. These heifers remained anoestrous for 11 months after the second booster, at which point they were injected with GnRH and PGF-2 $\alpha$; only 1 heifer resumed ovarian cyclicity. These results indicate that it is possible to increase ovarian activity in cattle by active immunization against testosterone, but that there is a high incidence of anoestrus.
\end{abstract}

\section{Introduction}

The use of immunological techniques to increase prolificacy in sheep has been widely explored. Active immunization against oestrone, androstenedione and testosterone has been shown to increase ovulation and lambing rates (Scaramuzzi et al., 1977; Cox et al., 1982; Croker et al., 1982). However, immunization against oestradiol-17 $\beta$, and occasionally oestrone and testosterone, has been reported to result in a high incidence of blocked or delayed oestrous cycles (Rawlings et al., 1978; Martensz \& Scaramuzzi, 1979; Scaramuzzi et al., 1980). Less successful attempts have been made to immunize cattle against steroids to induce twinning. Active immunization against oestradiol-17 $\beta$ has been shown to disrupt or to have no effect on oestrous cycles (Martin et al., 1978; Wise \& Schanbacher, 1983), whilst increased ovulation and calving rates have been reported with immunization against androstenedione (Wise \& Schanbacher, 1983). To date, active

\footnotetext{
*Reprint requests to $\mathrm{R}$. Webb.

†Present address: Wallaceville Animal Research Centre, Research Division, Ministry of Agriculture and Fisheries, Private Bag, Upper Hutt, New Zealand.
} 
immunization against testosterone has only been reported in conjunction with PMSG-induced superovulation in heifers, when a further increase in ovulation rate was observed (Boland $e t$ al., 1985).

The objective of this study was to assess the effects of actively immunizing heifers against a testosterone conjugate on ovulation rate, oestrous cycle length and peripheral serum hormone concentrations.

\section{Materials and Methods}

Animals. Seventeen Charolais and Simmental cross yearling heifers were studied at the Institute farms in Scotland. They were housed indoors during winter months and fed hay and standard concentrate, with fresh water available ad libitum.

Materials. The adjuvants were prepared using Non-Ulcerative (incomplete) Freund's Adjuvant (NUFA; Guildhay Antisera, University of Surrey), Corynebacterium parvum and Bordetella pertussis (Wellcome Biotechnology Ltd, Beckenham, Kent).

Protocol. The heifers were divided into two treatment groups of 4 and a control group of 9 animals. The treatment animals were immunized by injection with $8 \mathrm{mg}$ testosterone-3-carboxymethyloxime-ovalbumen (Land et al., 1982) dissolved in Adjuvant A. $(1.5 \mathrm{ml}$ NUFA plus $1.5 \mathrm{ml} 0.9 \%$ sterile saline; Travenol Laboratories Ltd, Thetford, Norfolk; Group A) or Adjuvant B (1.5 ml NUFA, $0.5 \mathrm{ml}$ sterile saline and $1.0 \mathrm{ml} \mathrm{C.} \mathrm{parvum;} \mathrm{Group} \mathrm{B)} \mathrm{given} \mathrm{intra-}$ muscularly at 4 sites, in conjunction with $2.5 \mathrm{ml} \mathrm{B}$. pertussis injected subcutaneously in the brisket. The control animals (Group C) were not injected.

After the priming injection, heifers in Groups A and B were given two booster injections at 4-month intervals; the first booster was of the same composition as the priming injection, but the second booster was devoid of C. parvum and $B$. pertussis.

Jugular blood samples were taken by vacutainer 3 times weekly after the second booster injection for determinations of antibody titre and serum progesterone and basal luteinizing hormone (LH) concentrations. In addition, control animals were sampled, through jugular cannulae, every $10 \mathrm{~min}$ for $12 \mathrm{~h}$ for LH and follicle-stimulating hormone (FSH) profile determinations during the luteal (Day 10-12) and follicular (Day 17-19) phases of the oestrous cycle. Immunized animals which showed regular oestrous cycles were sampled as for the control heifers, and those which appeared to be anoestrous were sampled for one period of $8 \mathrm{~h}$.

Observations for oestrus were made after the second booster injection, at least twice daily aided by an oestrus detection device (Kamar Inc., Steamboat Springs, Colorado, U.S.A.). Ovulation rate was determined after the second booster injection by counting fresh corpora lutea between Days 7 and 14 after oestrus at mid-ventral laparoscopy under general anaesthesia (Holland et al., 1981). The presence of abnormal ovarian structures was also noted at laparoscopy.

To compare the endocrine effects of immunoneutralization of gonadal steroids to those of ovariectomy, 3 heifers ovariectomized 8 months previously were similarly cannulated, and blood was sampled every 10 min for $6 \mathrm{~h}$.

Antibody characterization. Antibody titres were determined by the addition of $0.1 \mathrm{ml} 1: 50000$ dilution of each antiserum to $0.1 \mathrm{ml}$ phosphate-gelatin assay buffer $(0.1 \%$ swine gelatin in $0.05 \mathrm{M}$-phosphate-buffered saline, $\mathrm{pH} 7.5)$ with $0 \cdot \mathrm{I} \mathrm{ml}$ of a $\left[1,2,6,7-{ }^{3} \mathrm{H}\right]$ testosterone solution in assay buffer (Amersham International, Amersham, Bucks; sp. act. $93 \mathrm{Ci} / \mathrm{mmol}$; mean $( \pm$ s.e.m.) mass added per tube, $77 \cdot 1 \pm 2.8 \mathrm{pg})$. The reaction mixture was incubated overnight at $4^{\circ} \mathrm{C}$, then $1 \mathrm{ml}$ dextran-charcoal suspension (Pharmacia U.K. Ltd, Milton Keynes, Bucks; $25 \mathrm{mg}$ dextran $\mathrm{T}-70: 250 \mathrm{mg}$ charcoal in $100 \mathrm{ml}$ assay buffer) was added and all tubes were incubated for a further $30 \mathrm{~min}$ at $4^{\circ} \mathrm{C}$ before centrifugation at $2000 \mathrm{~g}$ for $20 \mathrm{~min}$. The supernatant containing antiserum-bound testosterone was decanted into $3 \mathrm{ml}$ Fisosorb 4 (Fisons Scientific Apparatus Ltd, Loughborough, Leics.), mixed and counted. The titre was expressed as the percentage of added label bound by the dilution of antiserum present. Two types of serum sample were utilized in this assay for quality control. The negative control sample consisted of serum samples from the nonimmunized control heifers, added at initial dilutions of $1: 1000,1: 5000$ and 1:10000. The positive control sample consisted of a serum sample from a sheep previously immunized against testosterone, and was used at initial dilutions of 1:10000 and 1:100 000. The inter- and intra-assay coefficients of variation, based on 5 control duplicates in each of 8 assays, were $13 \cdot 0 \%$ and $5 \cdot 5 \%$, respectively.

The same procedure was adopted, with minor modifications, to assess the specificity (serum used at a dilution of 1:7000), and affinity (serum used at a dilution of 1:4000; unlabeiled testosterone added to cover the range $5-250 \mathrm{pg} /$ tube; $30 \cdot 7 \mathrm{pg}$ label added per tube) of the antisera.

Hormone assays. LH was measured by a direct radioimmunoassay using a solution of $0.01 \mathrm{M}$-sodium phosphate, pH 7.4, containing 0.15 M-sodium chloride, $0.1 \%$ bovine serum albumin (Sigma) and $0.01 \%$ thimerosal (Sigma) as the assay buffer. Bovine LH (USDA-bLH-I1) was radioiodinated by the chloramine-T method of Greenwood et al. (1963). The antiserum (R. B. Staigmiller, USDA, ARS, Montana Agric. Exp. Stn, Miles City, MT 59301) was raised in rabbits against a highly purified bovine LH preparation, and affinity purified on Sephadex 4B. When used at an initial dilution of 1:20000 the antibody bound $35-55 \%$ labelled $\mathrm{LH}$; this dilution was used throughout. The assay standard was USDA-bLH-B5, biopotency $2.1 \times$ NIH-LH-B9. 


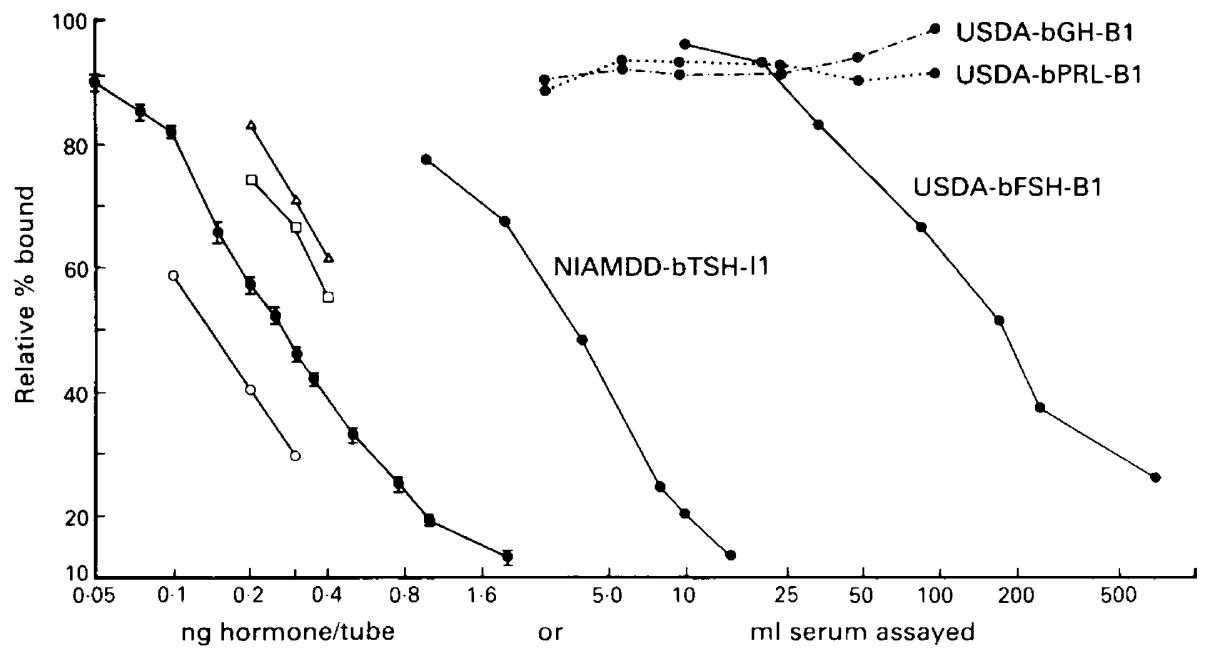

Fig. 1. Mean ( \pm s.e.m.) values for the standard curve, cross-reactivity and parallelism in the LH assay. Parallelism is demonstrated in several dilutions of serum from representative oestrous $(\square)$, ovariectomized $(O)$ and post-partum $(\triangle)$ cows.

The final assay procedure was as follows. Standard solutions and serum samples $(200 \mu l)$ were made up to $500 \mu l$ with assay buffer and $200 \mu \mathrm{l}$ of the antiserum were then added. The assay tubes were incubated at $4^{\circ} \mathrm{C}$ for $72 \mathrm{~h}$ before the addition of 12000 c.p.m. ${ }^{125}$ I-labelled LH in $100 \mu \mathrm{l}$ and a further incubation at $4^{\circ} \mathrm{C}$ for $72 \mathrm{~h}$. The bound and free fractions were separated by the addition of $100 \mu \mathrm{l}$ of a 1:400 dilution of normal rabbit serum and $200 \mu \mathrm{l}$ of a 1:45 dilution of donkey anti-rabbit serum (Scottish Antibody Production Unit; Carluke, Strathclyde), incubation at $4^{\circ} \mathrm{C}$ for $24 \mathrm{~h}$, the addition of $1 \mathrm{ml}$ assay buffer and then centrifugation at $2000 \mathrm{~g}$ for $30 \mathrm{~min}$ at $4^{\circ} \mathrm{C}$; the activity in the bound fraction was counted in a gamma counter after aspiration of the supernatant.

The specificity of the antiserum was assessed against various bovine pituitary hormones. Cross-reactivities were $5.5 \%$ for TSH, $0.6 \%$ for FSH and $<0.1 \%$ for growth hormone (GH) and prolactin. The apparent higher crossreactivity with the TSH standard was probably caused by contamination with immunoreactive LH; cattle given a bolus injection of TSH-releasing hormone (Protirelin; Roche, Welwyn Garden City, Herts) did not display elevations of serum LH (data not shown). Serum samples from oestrous, ovariectomized cows, and cows post partum, were assayed at various dilutions; all exhibited parallelism with the standard curve (Fig. 1). The accuracy of the assay was assessed by adding known amounts of standard ( 0.15 to $0.75 \mathrm{ng} /$ tube) to $300 \mu \mathrm{l}$ serum from cows post partum; after adjustment for endogenous LH in the samples, the mean recovery figure was $95.3 \pm 7.6 \%$. The sensitivity of the assay, defined as twice the standard deviation of blank values, was $0.07 \pm 0.01 \mathrm{ng} /$ tube over 6 assays. The inter-assay ( 6 assays) and intra-assay (20 duplicate samples) coefficients of variation were both $3.4 \%$ (control sera at 0.22 and $0.35 \mathrm{ng} /$ tube).

FSH was measured by the direct radioimmunoassay of Webb et al. (1980) with the following modifications. The assay buffer was that used in the LH assay. Ovine FSH (NIAMDD-oFSH-I1) was iodinated by the lactoperoxidase method of Thorrel \& Johansson (1971) and the standard used was USDA-bFSH-B1 (biopotency of $1.7 \times$ NIH-FSHB1). The antiserum (M94; previously validated by McNeilly et al., 1976) was added at a dilution of 1:1500 in a 1:400 dilution of normal rabbit serum (Scottish Antibody Production Unit) in assay buffer. The bound and free fractions were separated by the addition of $100 \mu \mathrm{l}$ of a 1:30 dilution of donkey anti-rabbit serum, in 1:10 diaminoethanetetraacetic acid disodium salt, followed by an overnight incubation at $4^{\circ} \mathrm{C}$ before the addition of $1 \mathrm{ml}$ assay buffer and centrifugation at $2000 \mathrm{~g}$ for $30 \mathrm{~min}$ at $4^{\circ} \mathrm{C}$. All samples were measured in one assay, with a sensitivity of $0.4 \mathrm{ng} /$ tube, and intra-assay coefficient of variation of $2.2 \%$ (estimated over 20 unknown samples). Serum progesterone determinations were made using a radioimmunoassay routinely used in this laboratory (Webb, 1987). Before assay, samples were extracted with petroleum ether plus $100 \mu \mathrm{l} 0.1 \mathrm{M}$-hydrochloric acid to denature protein-steroid complexes. The extraction efficiency was approximately $70 \%$, and the sensitivity of the assay was $0.12 \mathrm{ng} / \mathrm{ml}$. The inter- and intraassay coefficients of variation over 4 assays were 14.5 and $15.8 \%$, and 14.8 and $20.8 \%$, respectively, for pooled serum samples containing 1.5 and $3.0 \mathrm{ng} / \mathrm{ml}$.

Statistical analyses. Hormone data are presented as geometric means \pm s.e.m. The pulsatile nature of LH release was characterized by one of two methods. Firstly, data which showed a low-frequency, high-amplitude pulse profile were analysed by the pulse programme of Webb et al. (1985a), and the results expressed as number of pulses/12 $\mathrm{h}$. Secondly, data which showed a high frequency, low-amplitude pulse profile were analysed by a Genstat time series programme, and the results expressed at the time interval between pulses $(\mathrm{min})$. The validity of applying these techniques to different situations has been discussed by McLeod \& Craigon (1985). 
The affinities of the antisera raised against testosterone were calculated by the method of Scatchard (1949) after correction for non-specific binding (Chamness \& McGuire, 1975). Differences in measured parameters between groups were tested by Student's $t$ test.

\section{Results}

\section{Immunological response}

Of the 8 immunized heifers (Groups $\mathrm{A}$ and B), 7 displayed antibody responses after the second booster injection (Table 1). There were no apparent differences between the adjuvants, and so the treatment groups were pooled; the non-responding heifer (No. 624; Table 1) was discarded from the analysis. No animals developed any detectable lesions arising from the use of $C$. parvum. At the dilutions tested, the antisera were specific (cross-reactivities of $2.5 \%$ for androstenedione and $<0.6 \%$ for oestradiol- $17 \beta$, oestrone and progesterone) and of high affinity (mean affinity dissociation constant, $K_{\mathrm{d}}=3.5 \pm 0.4 \times 10^{-10} \mathrm{M}$ ). At no time did the titre for the negative control exceed $1 \cdot 5 \%$ binding of labelled testosterone, at an initial serum dilution of 1:1000.

Table 1. Antibody titres in all treatment animals, and overall mean titres, after the second booster injection

\begin{tabular}{|c|c|c|c|c|c|}
\hline & \multicolumn{5}{|c|}{ Titre* } \\
\hline & $\begin{array}{c}\text { Heifer } \\
\text { no. }\end{array}$ & Peak titre & 10 weeks & 25 weeks & 40 weeks \\
\hline Group A & $\begin{array}{l}553 \\
586 \\
590 \\
624\end{array}$ & $\begin{array}{r}11.8 \\
12.9 \\
23.6 \\
<0.5\end{array}$ & $\begin{array}{r}3.9 \\
6.5 \\
8.2 \\
<0.5\end{array}$ & $\begin{array}{r}14.2 \\
3.4 \\
3.0 \\
<0.5\end{array}$ & $\begin{array}{r}4.9 \\
-\dagger \\
1.4 \\
-\vdots\end{array}$ \\
\hline Group B & $\begin{array}{l}558 \\
566 \\
589 \\
601\end{array}$ & $\begin{array}{r}11 \cdot 1 \\
5 \cdot 7 \\
9 \cdot 7 \\
12 \cdot 4\end{array}$ & $\begin{array}{l}3 \cdot 4 \\
3 \cdot 5 \\
5 \cdot 0 \\
5 \cdot 2\end{array}$ & $\begin{array}{l}2.0 \\
1.9 \\
4 \cdot 2 \\
4.8\end{array}$ & $\begin{array}{l}0.8 \\
1.1 \\
1.5 \\
1.9\end{array}$ \\
\hline Treatmen & s.e.m.\$ & $12 \cdot 4 \pm 2 \cdot 1^{a}$ & $5 \cdot 1 \pm 0.7^{b}$ & $4 \cdot 8 \pm 1 \cdot 6^{b}$ & $1.9 \pm 0.6^{c}$ \\
\hline
\end{tabular}

*Expressed as percentage binding of added label $(77.2 \mathrm{pg} / \mathrm{tube})$ at a final antibody dilution of 1:150000, and are given at peak values (within 3 weeks of boosting), and at 10,25 and 40 weeks after booster.

†Heifer slaughtered 27 weeks after booster.

† Heifer did not respond to immunization and was discarded at 27 weeks.

$\$$ Means do not include values for Heifer 624 (non-responder). Mean values with different superscripts differ $(P<0.05)$.

\section{Ovarian responses}

After the second booster injection, all responding heifers were observed to be anoestrous, with abnormally large cystic structures on the ovaries at laparoscopy. The non-responding heifer continued to show regular oestrous cycles with single ovulations.

At about 25 weeks after the second booster, 3 heifers showed some oestrous activity. Heifer 558 gave two consecutive double ovulations, followed by one anovulatory cycle, and two consecutive cycles with single ovulations; cystic structures were seen on both ovaries at each occasion. This animal was intensively sampled for LH and FSH profiles after the second double ovulation. Heifer 586 exhibited one double ovulation accompanied by cystic structures, and then two consecutive single ovulations, again in the presence of ovarian cysts. This heifer was left undisturbed for several cycles and then ovariectomized at slaughter. Three mature corpora lutea were seen on one ovary, 
(a)
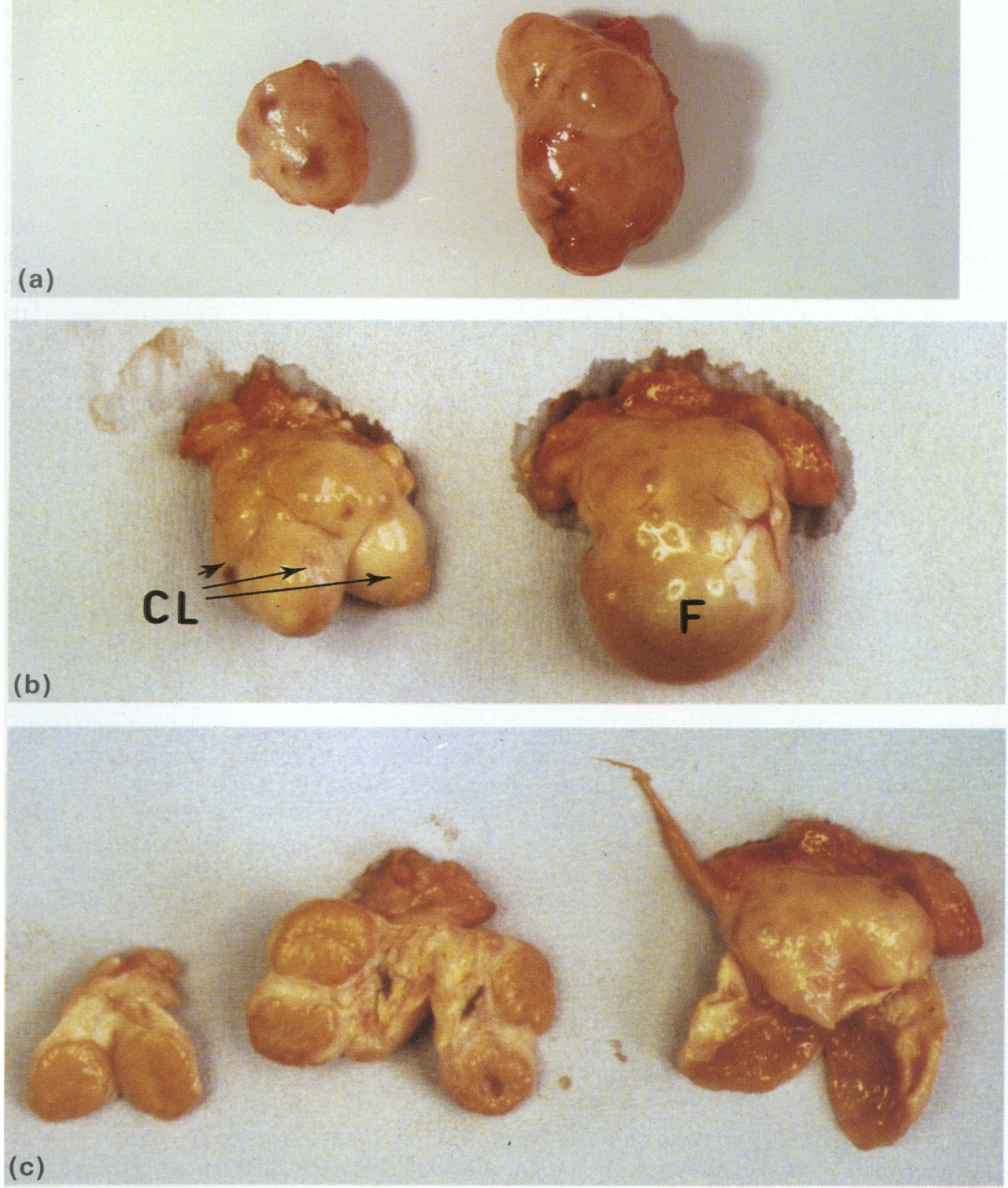

$\mathrm{cm}$

Fig. 2. Ovaries excised from (a) a control heifer, and (b) from an immunized heifer (No. 586) at slaughter and (c) after dissection. Note the presence of 3 corpora lutea (CL) on one ovary, and a luteinized follicle on the other $(F)$. 


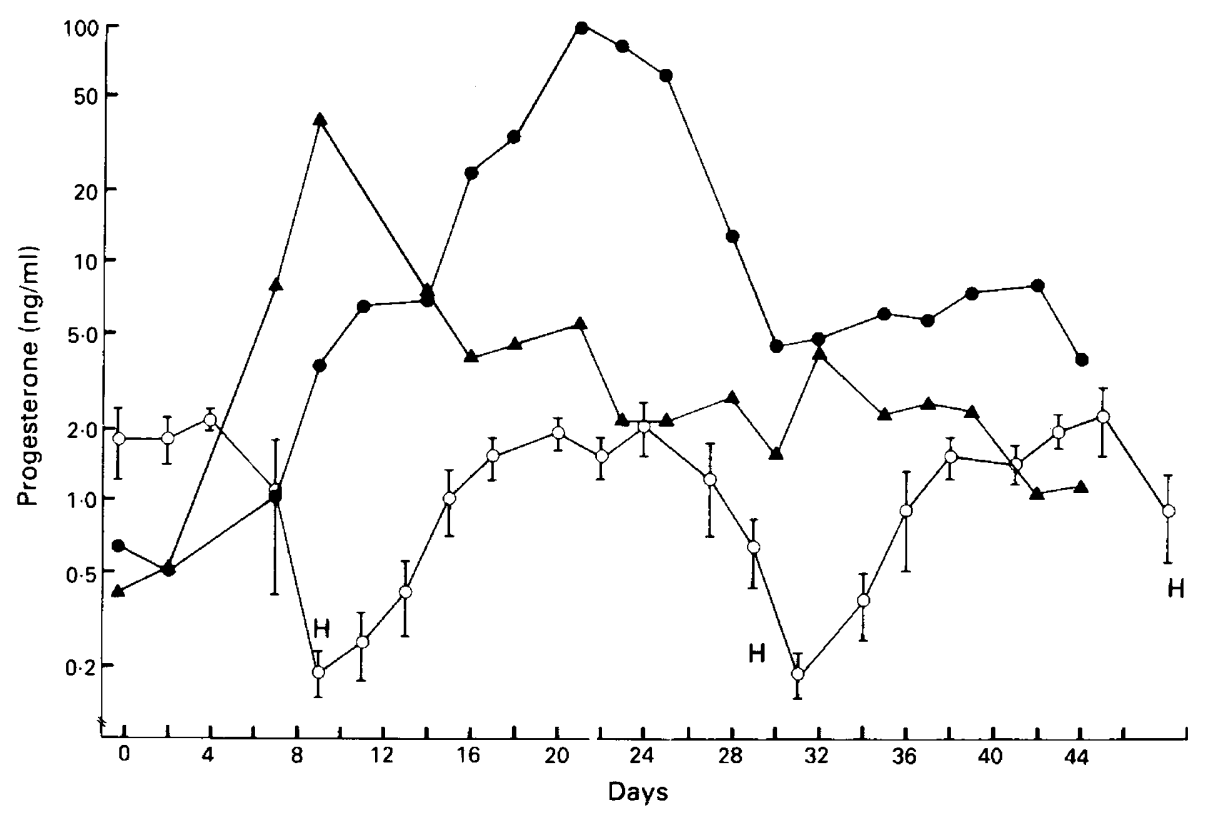

Fig. 3. Serum progesterone concentrations from two anoestrous, immunized heifers (No. 586, ; No. $553, \mathbf{\Delta})$ after the second booster injection. Also shown are the mean ( \pm s.e.m.) values for 6 control heifers $(O)$ adjusted for time of oestrus $(\mathrm{H})$. Note logarithmic scale on the $y$ axis.

and the contralateral ovary contained a large fluid filled cyst with a thick luteinized wall (Fig. 2) and a fluid volume of $7.5 \mathrm{ml}$. The antibody titre in this fluid, and follicular fluid from several other follicles, was similar to that in a serum sample also taken at slaughter (data not shown). The third heifer, No. 589, displayed 4 corpora lutea on one ovary and no cystic structures. This animal became anoestrous again, and laparoscopy revealed the 4 ovulations as corpora albicantia, plus one cyst but no fresh corpora lutea. Oestrus was not seen in this animal for a further 3 months, after which it was removed from the experiment because of injury. There was no correlation between antibody titre and oestrous activity at 25 weeks after boosting (see Table 1).

The remaining 4 immunized heifers showed sporadic signs of behavioural oestrus, but all were anovulatory and the ovaries were cystic. All control heifers continued to show regular oestrus; in a total of 62 laparoscopic observations, 8 indicated anovulation and two showed double ovulations.

\section{Progesterone concentrations}

Progesterone profiles were examined for a period of 6 weeks after the second booster injection. All anoestrous heifers showed very high concentrations which fluctuated irregularly, whilst control heifers showed regular cycles of progesterone secretion (Fig. 3).

At about 25 weeks after the second booster injection, the progesterone profiles from the multiple ovulating heifers (Nos 558, 586 and 589) showed a marked cyclic activity, although peak concentrations were still abnormally high $(16 \mathrm{ng} / \mathrm{ml}$, Heifer $558 ; 30 \mathrm{ng} / \mathrm{ml}$, Heifer 589$)$; at this time no control heifer showed concentrations higher than $6.5 \mathrm{ng} / \mathrm{ml}$. The 4 anoestrous, immunized heifers continued to exhibit irregular patterns of progesterone secretion.

\section{Gonadotrophin concentrations}

The mean basal LH concentrations in the serum of the immunized animals were significantly 
Table 2. Secretory pattern of LH and FSH in control and immunized heifers

\begin{tabular}{|c|c|c|c|c|c|}
\hline \multirow[b]{2}{*}{ Group } & \multirow[b]{2}{*}{$\begin{array}{l}\text { No. of } \\
\text { heifers }\end{array}$} & \multicolumn{3}{|c|}{ LH } & \multirow{2}{*}{$\begin{array}{c}\text { FSH } \\
\begin{array}{l}\text { Mean* } \\
(\mathrm{ng} / \mathrm{ml})\end{array}\end{array}$} \\
\hline & & $\begin{array}{l}\text { Mean* } \\
(\mathrm{ng} / \mathrm{ml})\end{array}$ & $\begin{array}{c}\text { Pulse } \\
\text { frequency } \\
\text { (per } 12 \mathrm{~h} \text { ) }\end{array}$ & $\begin{array}{c}\text { Pulse } \\
\text { interval } \\
\text { (min) }\end{array}$ & \\
\hline \multicolumn{6}{|l|}{ Control } \\
\hline Luteal phase. & 5 & $0.59 \pm 0.08^{\mathrm{a}}$ & $1.5 \pm 1.2$ & - & $17 \cdot 1 \pm 1 \cdot 6^{\mathrm{wx}}$ \\
\hline Follicular phase & 1 & $1.03 \pm 0.03^{b}$ & = & 48 & $19.5 \pm 1.8^{\mathrm{w}}$ \\
\hline Ovariectomized & 3 & $2 \cdot 32 \pm 0 \cdot 16^{d}$ & - & $31 \cdot 0 \pm 1 \cdot 0^{e}$ & $102 \cdot 9 \pm 9 \cdot 3^{y}$ \\
\hline \multicolumn{6}{|l|}{ Immunized } \\
\hline Luteal phase & 1 & $0.37 \pm 0.02^{\mathrm{c}}$ & 3 & - & $13 \cdot 6 \pm 1 \cdot 9^{x x}$ \\
\hline Follicular phase & 1 & $0.37 \pm 0.03^{c}$ & 5 & - & $7.9 \pm 0.9^{v}$ \\
\hline Anoestrus & 5 & $0.94 \pm 0.09^{b}$ & - & $32 \cdot 1 \pm 1 \cdot 1^{e}$ & $11 \cdot 4 \pm 1 \cdot 3^{2}$ \\
\hline
\end{tabular}

*Geometric means \pm s.e.m.

Within columns, mean values with different superscripts differ $(P<0.05)$.

(a) Luteal phase
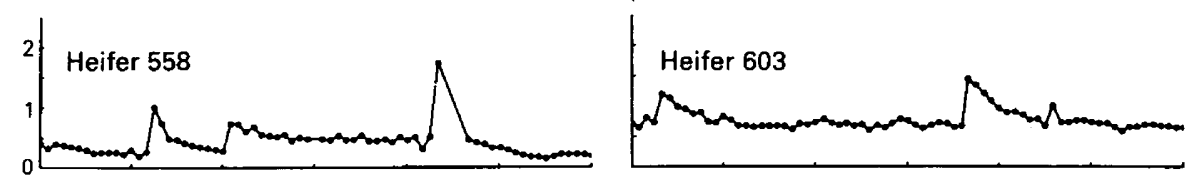

(b) Follicular phase
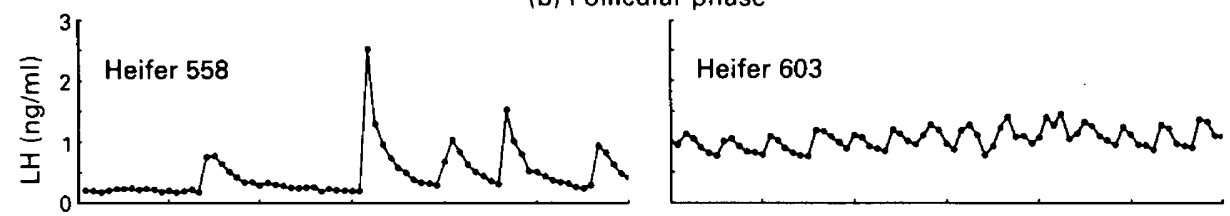

(c) Anoestrus
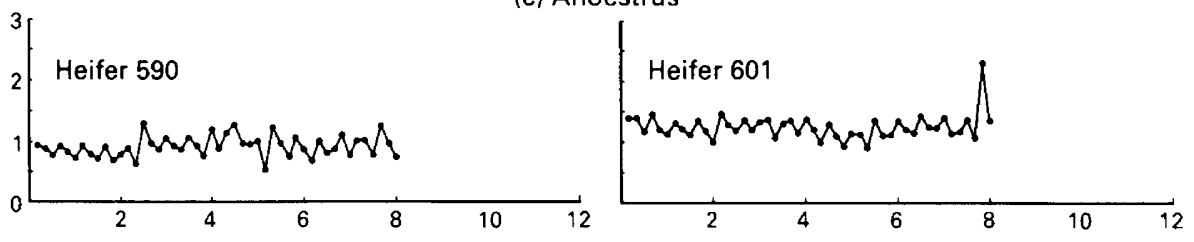

Hours

Fig. 4. Serum LH profiles during (a) the luteal phase and (b) the follicular phase, for a representative control (No. 603) and cyclic immunized heifer (No. 558), and (c) two anoestrous immunized heifers (Nos 601 and 590), about 25-30 weeks after the second booster. Samples were taken every $10 \mathrm{~min}$.

higher $(P<0.001)$ than those of control heifers $(1.01 \pm 0.03$ and $0.45 \pm 0.06 \mathrm{ng} / \mathrm{ml}$, respectively) just before, and did not change in response to, the second booster injection (data not shown).

The data from the LH and FSH intensive sampling periods are summarized in Table 2. Retrospective consideration of the progesterone data indicated that only one control heifer (No. 603) was in the follicular phase (see Schallenberger et al., 1984) and therefore is considered alone in Table 2. The LH profiles for the one immunized heifer showing oestrus at the time of sampling (No. 558), two anoestrous immunized heifers (Nos 590 and 601), and the representative control (No. 603) are given in Fig. 4.

The mean LH concentrations were different between cows of Group $\mathrm{C}$ in the luteal phase of the oestrous cycle and between the anoestrous, immunized heifers $(P<0.01)$, although the difference between these two groups was also significant $(P<0.05)$. There was no difference in mean LH 


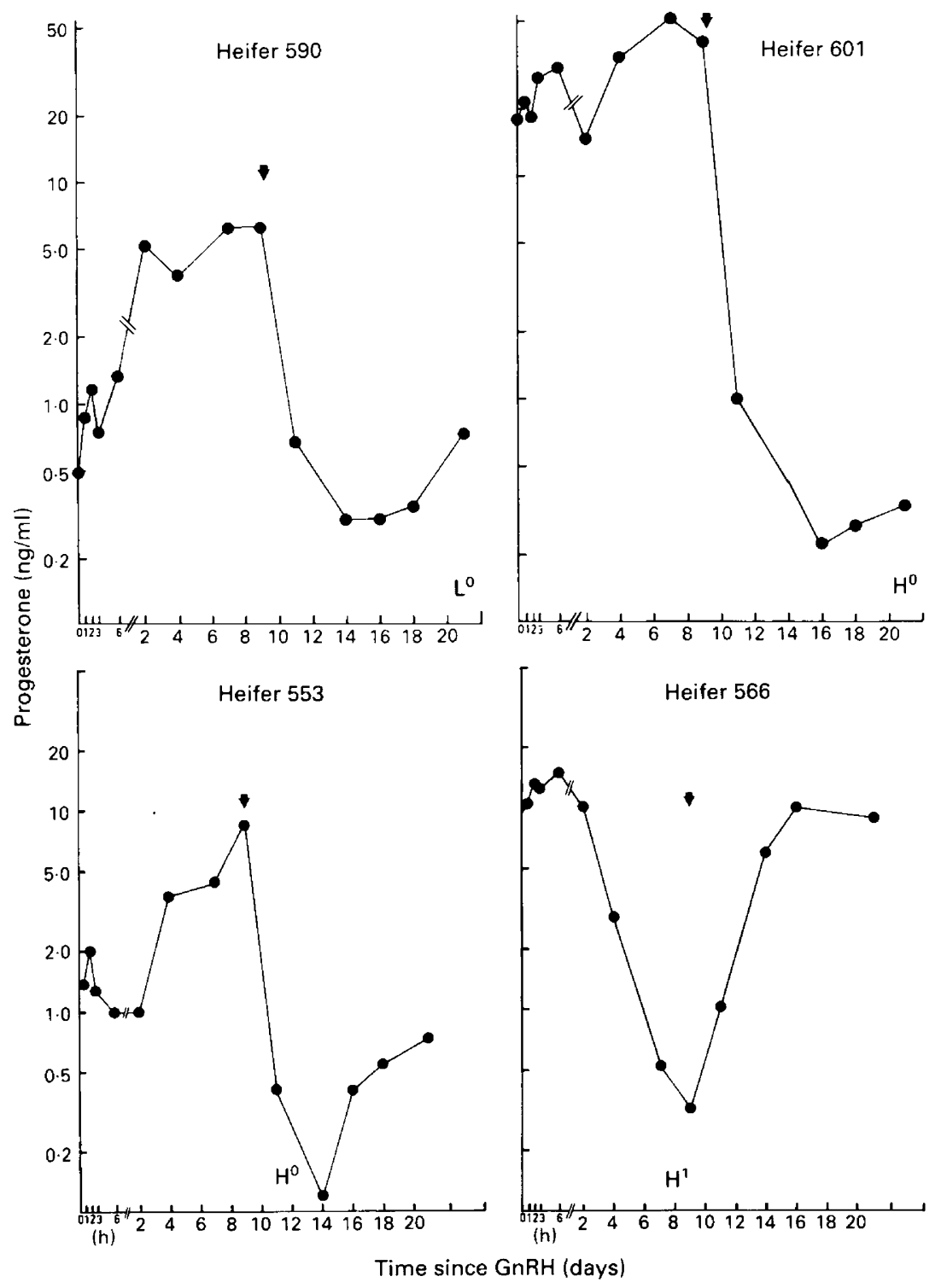

Fig. 5. Serum progesterone profiles from the anoestrous immunized heifers treated with GnRH and PGF- $2 \alpha$. $H$ and $L$ indicate occurrence of oestrus, and laparoscopy in the absence of oestrus, respectively, with superscripts indicating the number of corpora lutea observed on the ovary at laparoscopy. Arrows indicate injection of prostaglandin.

concentrations between the anoestrous heifers and the follicular-phase control heifer $(P>0.05)$. The cyclic, immunized heifer (No. 558) displayed similar mean luteal-phase and mean follicularphase LH concentrations, but these were significantly lower than those of control heifers in the luteal and follicular phases $(P<0.01)$. The mean LH pulse frequency in the anoestrous, immunized heifers was higher than that in the luteal-phase control animals, but not different from that of the ovariectomized heifers $(P>0.05)$. The mean $\mathrm{LH}$ concentration of the anoestrous heifers was significantly lower than that of the ovariectomized heifers $(P<0.05)$. Since time series 
analysis does not identify individual pulses, the pulse amplitudes could not be analysed, and therefore are not included in Table 2.

The mean FSH concentrations of the anoestrous, immunized heifers were significantly different between cows, and significantly lower than those of the controls $(P<0.05$; Table 2$)$. The immunized, cyclic heifer displayed a significantly lower mean FSH concentration in the follicular than the luteal phase $(P<0.05)$; there was no such difference overall between the control heifers, although the difference between phases within cows $(P<0.05)$ was different between cows $(P<0.05)$.

\section{Anoestrous immunized heifers}

The 4 remaining anoestrous heifers were allowed to remain undisturbed to establish whether falling antibody titres would lead to the resumption of oestrous cycles and an increased ovulation rate, as seen with Heifers 558,586 and 589 . However, ovulation was not observed by 40 weeks after the second booster (for antibody titre, see Table 1), and so it was decided to stimulate ovarian activity using an hormonal regimen designed for the treatment of dairy cows with polycystic ovaries (Kesler et al., 1978). Each heifer was given a bolus intramuscular injection of a synthetic gonadotrophin-releasing hormone (GnRH; $0.5 \mathrm{mg}$ in $5 \mathrm{ml}$; Fertagyl, Intervet, Cambridge, U.K.) followed 9 days later by a luteolytic dose of PGF-2 $\alpha$ ( $2 \mathrm{ml}$ Estrumate; ICI, Macclesfield, Cheshire). Animals were blood sampled at $0,1,2,3$ and $6 \mathrm{~h}$ after $\mathrm{GnRH}$ for LH surge detection, and 3 times weekly thereafter for 4 weeks for progesterone determinations. Observations for oestrus were continued for 2 months after the GnRH treatment. All heifers responded to the GnRH by releasing a surge of $\mathrm{LH}$ which peaked at $23.7 \pm 2.4 \mathrm{ng} / \mathrm{ml}$ after $2 \mathrm{~h}$ and fell to pretreatment concentrations within $6 \mathrm{~h}$. The rapid decline in progesterone seen in 3 of the 4 heifers as a result of the prostaglandin treatment (Fig. 5) confirms that the cystic structures observed were secreting progesterone. Three of the 4 anoestrous heifers showed behavioural oestrus in response to the treatment, but only one of these ovulated and showed regular oestrus thereafter (Heifer 566). The heifer which did not exhibit oestrus (No. 590) still possessed cystic ovaries, but displayed oestrus on two subsequent occasions at an interval of 21 days. The second oestrus was anovulatory.

\section{Discussion}

This study shows that active immunization of heifers against a testosterone conjugate can have profound effects on the reproductive system. All immunized heifers that had a detectable immune response became anoestrous for at least 6 months after immunization, and displayed a high incidence of ovarian cysts. Those heifers that resumed spontaneous oestrous activity did so with a high incidence of multiple ovulations.

Similar findings have been reported for testosterone-immunized rats (Hillier et al., 1975) and sheep (Scaramuzzi et al., 1981). Anoestrus and the subsequent onset of oestrous activity and multiple ovulations may be related to antibody titre (Cox et al., 1982), but in the present study, despite similar antibody affinities, there were no clear differences in titre between multiple ovulating and anoestrous heifers. However, difficulties arise when antibody characteristics are correlated with biological effects. The specificity of an antiserum at a final dilution of 1:21000 in vitro may be quite different from that undiluted in vivo. Similarly, different antibody populations can become evident when Scatchard analyses are conducted on antisera at progressively lower dilutions (see, for example, Webb et al., 1985b). In addition, neither of the above properties can be expected to remain constant after active immunization. The antibody titres measured in the present study declined gradually, but with some fluctuation as illustrated in Table 1 for Heifer 553 .

Antibody titre per se may not fully account for the duration of anoestrus seen in the current study, as the antibody titre levels for most of the animals were significantly lower 40 weeks after 
immunization than they were at 10 weeks (Table 1). Another factor may have been the presence of ovarian cysts, which can lead to long-term anoestrus and anovulation (see Seguin, 1980); GnRH and PGF- $2 \alpha$ administration caused the resumption of ovulation in at least one anoestrous heifer out of 4 , and caused consecutive displays of oestrus in another. Overstimulation of the ovaries by gonadotrophins has been implicated in the formation of cysts in cattle (Erb et al., 1971) and women (Mahesh \& Greenblatt, 1961).

The present findings of significantly increased mean LH concentrations and pulse frequency in the anoestrous, immunized heifers compared with those of control heifers would indicate a decrease in negative feedback to the hypothalamus/pituitary gland. It is known that in the cow LH and FSH are under the feedback control of oestradiol and progesterone (Beck et al., 1976; Beck \& Convey, 1977; Ireland \& Roche, 1982; Butler et al., 1983), but not testosterone (Thompson et al., 1984); the testosterone antibodies in the present study could therefore be acting to decrease negative feedback by cross-reacting with and neutralizing circulating oestradiol and progesterone in vivo or reducing oestradiol production at the ovarian level (Baird, 1977). The elevated LH secretion in the anoestrous, immunized heifers in the presence of high progesterone concentrations (Fig. 4 and Table 2) suggests at least partial neutralization of circulating progesterone.

Complete removal of ovarian feedback upon the hypothalamus/pituitary gland by ovariectomy is known to raise $\mathrm{LH}$ and FSH mean concentrations and LH pulse frequency in cattle (Hobson \& Hansel, 1972; Short et al., 1973; Forrest et al., 1980; Schallenberger \& Peterson, 1982). Comparison of ovariectomized heifers with the anoestrous, immunized heifers in the present study indicates that, whilst the present mean LH concentrations are significantly lower than those of an ovariectomized animal, the LH pulse frequency is as high as that of ovariectomized cows (Table 2). The reason for this differential effect of the treatment on $\mathrm{LH}$ secretion is unclear. The amplitude of the LH pulses in the anoestrous heifers appears low when compared visually to that of cyclic heifers, although a comparison with the ovariectomized heifers is difficult to make without statistical analysis. A low pulse amplitude could be produced by exhaustion of pituitary LH content or negative feedback by ovarian hormones as previously described for sheep (see review by Martin, 1984); neither of these can be ruled out in the present study. The pulse interval of the follicular-phase control heifer in the present study compares well with the estimates of Schallenberger et al. (1984). Similar effects on gonadotrophin secretion have also been reported for sheep actively and passively immunized against testosterone (Martensz \& Scaramuzzi, 1979; Martensz et al., 1979; Pathiraja, 1982; Pathiraja et al., 1984).

Testosterone antibodies within the follicle may influence gonadotrophin secretion and ovarian activity by directly reducing ovarian output of oestradiol and/or inhibin. Testosterone can act in concert with FSH to stimulate granulosa cell aromatase activity as well as acting as a substrate (Daniel \& Armstrong, 1980), and the administration of anti-testosterone serum into the ovarian artery has been shown to decrease ovarian oestradiol output in sheep (Baird, 1977). Testosterone has also been shown to stimulate ovarian inhibin production (Henderson \& Franchimont, 1983), and inhibin can decrease both serum FSH and ovarian activity in sheep and cattle (Miller et al., 1979; Ireland et al., 1983). Inhibin secretion is also stimulated by FSH (Tsonis et al., 1986). The depressed FSH concentrations seen in this study may therefore be a consequence of continued ovarian inhibin secretion.

In conclusion, this study demonstrates that ovulation rate in cattle can be increased by actively immunizing against testosterone, but that the high incidence of anoestrus makes this technique unsuitable for commercial use. Two further approaches that may increase fecundity in cattle are passive immunization against gonadal steroids and active immunization against inhibin, both of which are currently under investigation in our laboratory.

We thank the staff of the Dryden Laboratory, Roslin, for husbandry of cattle, recording of oestrus and assistance in surgery; Mr N. Russell for photographic services; Dr S. S. Lynch, Birmingham \& Midland Hospital for Women, and Dr R. B. Staigmiller and Dr D. J. Bolt, U.S. 
Department of Agriculture, for radioimmunoassay reagents; A. J. Springbett for statistical analyses; G. Baxter, D. McBride and Mrs N. B. Sharp, for assistance with the assays; and Mrs J. Cherrie for typing the manuscript. C.A.P. was in receipt of an AFRC Postgraduate Studentship. This work was funded in part by a grant from the CEC (No. 3710).

\section{References}

Baird, D.T. (1977) Evidence in vivo for the two-cell hypothesis of oestrogen synthesis by the sheep Graafian follicle. J. Reprod. Fert. 50, 183-185.

Beck, T.W. \& Convey, E.M. (1977) Estradiol control of serum luteinizing hormone concentrations in the bovine. J. Anim. Sci. 45, 1096-1101.

Beck, T.W., Smith, V.G., Seguin, B.E. \& Convey, E.M. (1976) Bovine serum LH, GH, and prolactin following chronic implantation of ovarian steroids and subsequent ovariectomy. J. Anim. Sci. 42, 461-468.

Boland, M.P., Nancarrow, C.D., Hoskinson, R.M., Murray, J.D., Scaramuzzi, R.J., Radford, H.M., Avenell, J.A. \& Bindon, B.M. (1985) Superovulatory response in cows following immunization against testosterone and treatment with bovine follicular fluid and PMSG. Theriogenology 23, 180, Abstr.

Butler, W.R., Katz, L.S., Arriola, J., Milvae, R.A. \& Foote, R.H. (1983) On the negative feedback regulation of gonadotropins in castrate and intact cattle with comparison of two FSH radioimmunoassays. $J$. Anim. Sci. 56, 919-929.

Chamness, G.C. \& McGuire, W.L. (1975) Scatchard plots: common errors in correction and interpretation. Steroids 26, 538-542.

Cox, R.I., Wilson, P. A., Scaramuzzi, R.J., Hoskinson, R.M., George, J.M. \& Bindon, B.M. (1982) The active immunisation of sheep against oestrone, androstenedione or testosterone to increase twinning. Proc. Aust. Soc. Anim. Prod. 14, 511-514.

Croker, K.P., Cox, R.I., Johnson, T.J. \& Wilson, P.A. (1982) The immunization of Merino sheep in Western Australia against steroids as a means of increasing fecundity. Proc. Aust. Soc. Anim. Prod. 14, 96, Abstr.

Daniel, S.A.J. \& Armstrong, D.T. (1980) Enhancement of follicle-stimulating hormone-induced aromatase activity by androgens in cultured rat granulosa cells. Endocrinology 107, 1027-1033.

Erb, R.E., Surve, A.H., Callahan, C.J., Randel, R.D. \& Garverick, H.A. (1971) Reproductive steroids in the bovine. VII. Changes post-partum. J. Anim. Sci. 33, 1060-1071.

Forrest, D.W., Fleeger, J.L., Long, C.R., Sorensen, A.M. \& Harms, P.G. (1980) Effect of exogenous prolactin on peripheral luteinizing hormone levels in ovariectomized cows. Biol. Reprod. 22, 197-201.

Greenwood, F.C., Hunter, W.M. \& Glover, J.S. (1963) The preparation of ${ }^{131}$ I-labelled human growth hormone of high specific radioactivity. Biochem. J. 89, 114-123.

Henderson, K.M. \& Franchimont, P. (1983) Inhibin production by bovine ovarian tissues in vitro and its regulation by androgens. J. Reprod. Fert. 67, 291-298.
Hillier, S.G., Groom, G.V., Boyns, A.R. \& Cameron, E.H.D. (1975) Effects of active immunisation against steroids upon circulating hormone concentrations. $J$. Steroid Biochem. 6, 529-535.

Hobson, W.C. \& Hansel, W. (1972) Plasma LH levels after ovariectomy, corpus luteum removal and estradiol administration in cattle. Endocrinology 91, 185-190.

Holland, E.J., Bindon, B.M., Piper, L.R., Thimonier, J., Cornish, K.A. \& Radford, H.M. (1981) Endoscopy in cattle: techniques for ovarian examination by the paralumbar and mid-ventral routes. Anim. Reprod. Sci. 4, 127-135.

Ireland, J.J. \& Roche, J.F. (1982) Effect of progesterone on basal LH and episodic LH and FSH secretion in heifers. J. Reprod. Fert. 64, 295-302.

Ireland, J.J., Curato, A.O. \& Wilson, J. (1983) Effect of charcoal-treated bovine follicular fiuid on secretion of LH and FSH in ovariectomised heifers. J. Anim. Sci. 57, 1512-1516.

Kesler, D.J., Garverick, H.A., Caudle, A.B., Bierschwal, C.J., Elmore, R.G. \& Youngquist, R.S. (1978) Clinical and endocrine responses of dairy cows with ovarian cysts to GnRH and PGF2a. J. Anim. Sci. 46, 719-725.

Land, R.B., Morris, B.A., Baxter, G., Fordyce, M. \&, Forster, J. (1982) Improvement of sheep fecundity by treatment with antisera to gonadal steroids. $J$. Reprod. Fert. 66, 625-634.

Mahesh, V.B. \& Greenblatt, R.B. (1961) Physiology and pathogenesis of the Stein-Leventhal syndrome. Nature, Lond. 191, 888-890.

Martensz, N.D. \& Scaramuzzi, R.J. (1979) Plasma concentrations of luteinizing hormone, follicle-stimulating hormone and progesterone during the breeding season in ewes immunized against androstenedione or testosterone. J. Endocr. 81, 249-259.

Martensz, N.D., Scaramuzzi, R.J. \& Van Look, P.F.A. (1979) Plasma concentrations of luteinizing hormone and follicle-stimulating hormone during anoestrus in ewes actively immunized against oestradiol-17及, oestrone or testosterone. J. Endocr. 81, 261-269.

Martin, G.B. (1984) Factors affecting the secretion of luteinizing hormone in the ewe. Biol. Rev. 59, 1-87.

Martin, T.E., Henricks, D.M., Hill, J.R. \& Rawlings, N.C. (1978) Active immunization of the cow against oestradiol-17ß. J. Reprod. Fert. 53, 173-178.

McLeod, B.J. \& Craigon, J. (1985) Time series analysis of plasma LH and FSH concentrations as a method of assessing episodic secretion. J. Reprod. Fert. 74, 575-587.

McNeilly, J.R., McNeilly, A.S., Walton, J.S. \& Cunningham, F.J. (1976) Development and appli- 
cation of a heterologous radioimmunoassay for ovine follicle-stimulating hormone. J. Endocr. 70, 69-79.

Miller, K.F., Critser, J.K., Rowe, R.F. \& Ginther, O.J. (1979) Ovarian effects of bovine follicular fluid treatment in sheep and cattle. Biol. Reprod. 21, 537-544.

Pathiraja, N. (1982) Physiological basis of genetic variation in ovulation rate. Ph.D. thesis, University of Edinburgh.

Pathiraja, N., Carr, W.R., Fordyce, M., Forster, J., Land, R.B. \& Morris, B.A. (1984) Concentration of gonadotrophins in the plasma of sheep given gonadal steroid antisera to raise ovulation rate. $J$. Reprod. Fert. 72, 93-100.

Rawlings, N.C., Kennedy, S.W. \& Henricks, D.M. (1978) Effect of active immunization of the cyclic ewe against oestradiol-17ß. J. Endocr. 76, 11-19.

Scaramuzzi, R.J., Baird, D.T., Clarke, I.J., Davidson, W.G., Martensz, N.D. \& Van Look, P.F.A. (1977) Ovulation and oestrus following active immunisation against ovarian steroids. Acta endocr., Copenh., Suppl. 212, 41, Abstr. 32.

Scaramuzzi, R.J., Martensz, N.D. \& Van Look, P.F.A. (1980) Ovarian morphology and the concentration of steroids, and of gonadotrophins during the breeding season in ewes actively immunised against oestradiol$17 \beta$ or oestrone. J. Reprod. Fert. 59, 303-310.

Scaramuzzi, R.J., Baird, D.T., Martensz, N.D., Turnbull, K.E. \& Van Look, P.F.A. (1981) Ovarian function in the ewe after active immunization against testosterone. J. Reprod. Fert. 61, 1-9.

Scatchard, G. (1949) The attraction of proteins for small molecules and ions. Ann. N.Y. Acad. Sci. 51, 660-672.

Schallenberger, E. \& Peterson, A.J. (1982) Effect of ovariectomy on tonic gonadotrophin secretion in cyclic and post-partum dairy cows. J. Reprod. Fert. $64,47-52$.

Schallenberger, E., Schams, D., Bullerman, B. \& Walters, D.L. (1984) Pulsatile secretion of gonadotrophins, ovarian steroids and ovarian oxytocin during prostaglandin-induced regression of the corpus luteum in the cow. J. Reprod. Fert. 71, 493-501.
Seguin, B. (1980) Ovarian cysts in dairy cows. In Current Therapy in Theriogenology, pp. 199-204. Ed. D. A. Morrow. W. B. Saunders Company, Philadelphia.

Short, R.E., Howland, B.E., Randel, R.D., Christensen, D.S. \& Bellows, R.A. (1973) Induced LH release in spayed cows. J. Anim. Sci. 37, 551-557.

Thompson, D.L., Voelkel, S.A., Reville-Moroz, S.I., Godke, R.A. \& Derrick, D.J. (1984) Testosterone effects on gonadotropin response to GNRH: cows and pony mares. J. Anim. Sci. 58, 409-415.

Thorrel, J.I. \& Johansson, B.G. (1971) Enzymatic iodination of polypeptides with ${ }^{125}$ I to high specific activity. Biochem. Biophys. Acta 251, 363-367.

Tsonis, C.G., McNeilly, A.S. \& Baird, D.T. (1986) Measurement of exogenous and endogenous inhibin in sheep serum using a new and extremely sensitive bioassay for inhibin based on inhibition of ovine pituitary FSH secretion in vitro. J. Endocr. 110, 341-352.

Webb, R. (1987) Increasing ovulation rate and lambing rate in sheep by treatment with a steroid enzyme inhibitor. J. Reprod. Fert. 79, 231-240.

Webb, R., Lamming, G.E., Haynes, N.B. \& Foxcroft, G.R. (1980) Plasma progesterone and gonadotrophin concentrations and ovarian activity in post-partum dairy cows. J. Reprod. Fert. 59, 133-143.

Webb, R., Baxter, G., Preece, R.D., Land, R.B. \& Springbett, A.J. (1985a) Control of gonadotrophin release in Scottish Blackface and Finnish Landrace ewes during seasonal anoestrus. J. Reprod. Fert. 73, 369-378.

Webb, R., Baxter, G., McBride, D., Nordblom, G.D. \& Shaw, M.P.K. (1985b) The measurement of testosterone and oestradiol-17 $\beta$ using iodinated tracers and incorporating an affinity chromatography extraction procedure. J. Steroid Biochem. 23, 1043-1051.

Wise, T.H. \& Schanbacher, B.D. (1983) Reproductive effects of immunizing heifers against androstenedione and oestradiol-17\%. J. Reprod. Fert. 69, $605-612$. 